\title{
Narrativas na Comunicação:
}

\section{A persistência mitogênica \\ Communication narratives:}

\section{Mitogenic persistence}

\section{Por Ana Taís Martins}

\section{Mito, superestrutura do imaginário}

São abundantes nas comunicações e nas artes contemporâneas as referências à continuidade da narrativa mítica nos dias atuais. A analogia entre os mitos arcaicos e as produções artísticas, culturais, midiáticas e também sociais e políticas é facilmente estabelecida. No entanto, antes de afirmar que Vênus se encarna em Beyoncé, que a Mulher Maravilha é mesmo Diana ou que Aquiles e Netuno são reatualizados nas telas dos cinemas em papeis desempenhados por Brad Pitt e Jason Momoa, seria de se indagar sobre pertinência dessas aproximações sob o ponto de vista do sermo mythicus. A pergunta, então, não é qual mito parasita esse ou aquele fato da contemporaneidade, e sim qual é a eficácia simbólica dessa parasitagem. O mito é a forma da organização das imagens simbólicas que mais se aproxima do inconsciente antropológico, sendo já consciência e racionalização. Assim, por conservar sua pregnância simbólica1, ao mesmo tempo em que se apresenta tangível, o mito ocupa um lugar determinante nas dinâmicas do imaginário.

Muito embora Sartre (1986), já em 1940, tenha intitulado uma de suas obras como "O imaginário", foi somente a partir do trabalho de Gilbert Durand, vinte anos mais tarde, que se definiu e se sistematizou uma compreensão não negativa do imaginário. Ao definir o imaginário como o resultado da gênese recíproca² entre as coerções do meio social e as pulsões, Durand (2016) é bem sucedido, ao mesmo tempo, em restringir suficientemente a noção para dela eliminar o caráter

\footnotetext{
1 Cassirer (1998) utilizou a expressão pregnância simbólica para indicar que quaisquer dados recebidos pelo sujeito são já impregnados de sentido, não existindo, portanto, dados puros. Ao sublinharem a ideia de que o simbólico tem seu sentido motivado e não arbitrário, os Estudos do Imaginário encontram enorme utilidade nessa expressão emprestada de Cassirer.

2 Durand utiliza a expressão "gênese recíproca" retomando Piaget (apud DURAND, 2016, p. 38), que a define pelo "equilíbrio móvel" e pela "reversibilidade".
} 


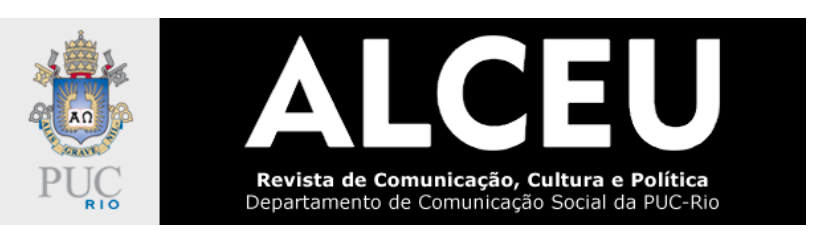

de receptáculo para tudo que não se compreenda bem e ampliá-la suficientemente para abrigar as produções culturais desde as mais enrijecidas simbolicamente, como os estereótipos e mesmo os preconceitos, até as mais férteis e exclusivas, como a arte.

De fato, as forças que dinamizam o imaginário não distinguem entre o que é arte e o que não é, entre o estereótipo e o preconceito: enquanto patrimônio antropologicamente partilhado, o imaginário abriga as respostas possíveis que o Sapiens dá à resistência que o mundo lhe oferece. No entanto, nem todas as imagens se equiparam em pregnância simbólica, variando conforme sua posição no trajeto antropológico ou trajeto do sentido (DURAND, 2016), que define, em grandes linhas, o dinamismo do imaginário, o nascimento das imagens a partir da interação entre dois polos ao mesmo tempo opostos e auto-generativos, e também o movimento das imagens ao longo desse percurso. Um dos polos, chamado pulsional, abriga aquilo que já nasce com o ser humano, seu corpo e três reflexos dominantes (em presença dos quais os demais se abrandam ou se anulam), a saber, o reflexo postural (tendência ao bipedismo), nutricional ou digestivo e rítmico ou copulativo. O outro polo, chamado coercitivo, abriga o meio material e social, as injunções que o mundo e a sociedade impõem ao ser. As imagens simbólicas, conforme Durand (2016), são precisamente resultado dessa negociação entre pulsões e coerções.

Os reflexos dominantes que se encontram na base do polo pulsional se prolongam em schèmes, palavra usada por Durand (2016) e que preferimos não traduzir por esquema para não confundir com esquema (schéma). Na teoria geral do imaginário, a noção de schème tem grande importância, sendo ele mesmo anterior ao arquétipo, o qual também participa de um nível do imaginário entendido como sendo o inconsciente antropológico. Os schèmes remetem a ações que, repetidas em situações análogas, se transformam ou se generalizam, traduzindo os reflexos dominantes em imagens.

Assim, o reflexo postural se desdobra nos schèmes ascensional, diairético e especular porque a postura bípede indica uma tendência à subida, libera as mãos e a visão para distinguir e agir, além de acrescentar a matéria luminosa à experiência. O reflexo digestivo se dinamiza no schème da descida, referente à descida digestiva, e o reflexo copulativo nos schèmes rítmico e progressivo. Durand (2016) relembra a equação de Leroi-Gourhan, força + matéria = ferramenta, para afirmar que cada um desses gestos faz apelo ao mesmo tempo a uma matéria e a uma técnica, criando um material imaginário e uma ferramenta ou, no mínimo, um utensílio: 
É assim que o primeiro gesto, a dominante postural, exige as matérias luminosas, visuais e as técnicas de separação, de purificação, das quais as armas, as flechas, os gládios são símbolos frequentes. O segundo gesto, ligado à descida digestiva, convoca as matérias da profundidade: a água ou a terra cavernosa suscita os utensílios continentes, as taças e os cofres, e tende aos devaneios técnicos da bebida e do alimento. Enfim, os gestos rítmicos, dos quais a sexualidade é o modelo natural acabado, se projetam sobre os ritmos sazonais e seu cortejo astral anexando todos os substitutos técnicos do ciclo : a roda e o fuso, o pilão e o isqueiro, e finalmente sobredeterminam toda a fricção tecnológica pela rítmica sexual (DURAND, 2016, p. 55, tradução nossa³).

As imagens abstratas dos schèmes adquirem espessura com os arquétipos. Enquanto os schèmes se atêm cada um a suas próprias lógicas, os arquétipos reúnem forças contraditórias, ou seja, abrigam lógicas diferentes. Na trilha de Jung (2014), os arquétipos são intangíveis, residem no inconsciente antropológico e a partir dali exercem sua força pulsional na criação das imagens simbólicas. Eles vão se agrupar segundo lógicas derivadas dos schèmes, mas isso ocorre somente no momento em que são conscientizados e, portanto, já não são mais arquétipos. Quando conseguimos detectá-los, já se tornaram conscientes, ou seja, já perderam sua característica arquetípica - por isso, talvez possamos diagnosticar imagens arquetípicas, parcialidades dos arquétipos, mas jamais o arquétipo inteiro. Junto com os schèmes, os arquétipos são elementos invariantes, grandes eixos do imaginário e que indicam um simbolismo central, revelador da permanência do arcaico nas atualizações da experiência humana.

Essas atualizações se fazem por meio do mito ou do sermo mythicus, construção que se manifesta à consciência constituída por constelações de imagens simbólicas impulsionadas por um schème, materializadas por arquétipos, atraídas umas às outras por homologias - e não por analogia, ou seja, são imagens que têm a mesma origem (um mesmo schème), mas não necessariamente a mesma função. Embora, no trajeto antropológico, seja possível, abstratamente, distinguir entre schème, arquétipo, mito e símbolos, e mesmo seja possível identificar imagens simbólicas isoladas, esse procedimento não é útil porque o sentido do imaginário acontece em torno de narrativas, contextos vivenciados - relembremos o caráter motivado do símbolo e o simbólico como atributo da apreensão de uma imagem, e não como propriedade da imagem. O

\footnotetext{
${ }^{3}$ No original francês: "C'est ainsi que le premier geste, la dominante posturale, exige les matières lumineuses, visuelles et les techniques de séparation, de purification dont les armes, les flèches, les glaives sont les fréquents symboles. Le second geste, lié à la descente digestive, appelle les matières de la profondeur: l'eau ou la terre caverneuse, suscite les ustensiles contenants, les coupes et les coffres, et incline aux rêveries techniques du breuvage ou de l'aliment. Enfin les gestes rythmiques, dont la sexualité est le modèle naturel accompli, se projettent sur les rythmes saisonniers et leur cortège astral en annexant tous les substituts techniques du cycle : la roue comme la route, la baratte comme le briquet, et finalement surdéterminent tout frottement technologique par la rythmique sexuelle".
} 


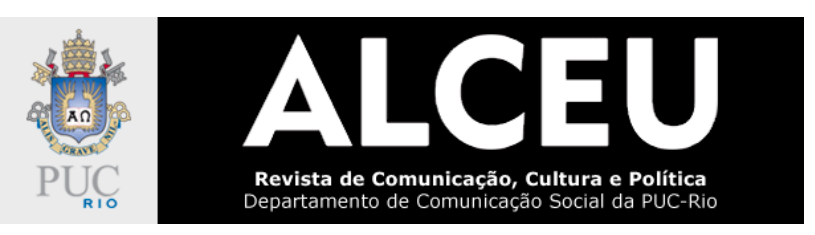

sentido que orienta o antropológico é dado, então, pelo sermo mythicus, e não por imagens isoladas. Pode-se mesmo afirmar que o mito é uma superestrutura que direciona e embasa as demais produções humanas.

\section{Nas constelações simbólicas, o fulcro do sentido}

Seja considerando-se o imaginário de modo geral, seja considerando-se os imaginários delimitados culturalmente, a organização das imagens simbólicas em sermo mythicus se dá dinamicamente, a partir delas mesmas, o que Durand (2016) chamou de estruturalismo figurativo. O acento, então, é mais na imagem do que na estrutura, já que esta não é pré-estabelecida, não é estável, e sim determinada na medida em que o simbolismo se organiza. Gestos reflexológicos e pulsões incitam o dinamismo do imaginário por um lado, enquanto, no outro extremo do trajeto antropológico (DURAND, 2016), fazendo força coercitiva, estão as estruturas sociais. Estas, apesar de terem também sua origem no subsolo do inconsciente antropológico, ao se estabilizarem institucionalmente entram em tensão com as pulsões originárias - aí está, como se viu, a origem das imagens simbólicas que se tornam apreensíveis no contexto de um sermo mythicus, já portador da tendência racional.

Quanto mais um mito se aproxima, no seu trajeto, da extremidade institucionalizada, onde residem as coerções sociais, mais se desbasta sua característica pulsional, mais "civilizado" se torna, perdendo, nesse processo, grande parte de sua polissemia e, como compensação (ainda que jamais suficiente) dessa perda, suas imagens se multiplicam. Reduzidas que são a alguns poucos significados (o sentido já se distanciou), não merecem mais o epíteto de simbólicas, sua experiência não suscitando a perturbação fundamental do símbolo, uma experiência antes apaziguadora, confirmadora do que já se sabe - essas imagens talvez se aproximem mais de estereótipos e de preconceitos.

Wunenburger (2018) utiliza uma árvore como metáfora para mostrar esse percurso das imagens, que iniciaria nas raízes, no subsolo antropológico e arquetipal, chamado de imaginal no sentido que Corbin (1976) atribui ao termo, onde habitariam as representações imajadas do surreal, que não têm modelos na experiência. Em seguida, o percurso passaria pelo imaginário, representado pelo tronco da árvore, onde circulariam "[...] as imagens que se apresentam antes como substituições de um real ausente" (WUNENBURGER, 2018, p. 67), chegando à imageria, representada pelas folhas, onde as imagens se relacionam com o mundo exterior, tentam 
reproduzi-lo, tendo nele seus referentes. Não obstante a introdução da ideia de imaginário como uma parte desse conjunto, e não como o "[...] o conjunto de imagens e de relações de imagens que constitui o capital pensado do Sapiens" (DURAND, 2016, p. XVII, grifo nosso, tradução nossa ${ }^{4}$ ) ou como "(...) dinamismo organizador de imagens que lhes confere profundidade e as liga entre si" (THOMAS, 1998, p. 16), a metáfora da árvore é útil por deixar claro que nem todas as imagens têm o mesmo grau de pregnância simbólica, embora tenham sempre no símbolo sua natureza.

Não será demais sublinhar mais uma vez que o simbólico pertence ao processo de vivência das imagens, não sendo, pois, seu atributo. Isso porque o simbólico, de acordo com a teoria geral do imaginário, é motivado e experienciado, tem um sentido mais do que um significado. Sendo assim, do simbólico é possível, ao mesmo tempo, rastrear o enraizamento (schématique e arquetipal) e projetar tendências, já que ele se define por dinâmicas, e não por cristalizações codificadas social e/ou culturalmente, ainda que essas codificações atuem sobre ele sob forma de coerções. Não sendo codificado nem codificável, o simbólico no seu grau máximo precisa ser vivido antes de ser compreendido. Seu entendimento não mobiliza referências: trata-se de uma revelação. Isso o torna dificilmente acessível a partir da consciência racionalizante. Pautando-se pelo vivido, pelo experimentado, mesmo pelo revelado, o simbólico não é propriedade de coisas, fatos, fenômenos, e sim condição de seu acontecimento. É precisamente essa a consequência de a figuração anteceder o conceito, de o sentido conotativo estar a serviço do denotativo; caso contrário, as imagens servirão apenas para ilustrar conceitos já construídos, não indo muito além do papel de alegorias, como afirma Wunenburger (2002, p. 43, tradução nossa): "Em primeiro lugar, o imaginário não tem real acesso à simbolicidade se não estiver liberado de toda função alegorizante na qual o conceito precede sempre a produção da imagem"5.

Portanto, a dimensão simbólica não pode ser discutida por meio da descrição de imagens para relacioná-las com símbolos ou da construção de analogias entre narrativas contemporâneas e arcaicas. Também é anódina a classificação de uma imagem como estereótipo ou preconceito. A descrição metódica de imagens e sua inserção em um universo de referências é antes um trabalho do ser cultural que há no sujeito, é um processo diacrônico, enquanto o impacto imediato que uma obra causa fala ao ser mítico, é um processo sincrônico que prescinde de explicações. É

\footnotetext{
${ }^{4}$ No original francês: "[...] l'ensemble des images et des relations d'images qui constitue le capital pensé de l'homo sapiens".

${ }^{5}$ No original francês: "D'abord l'imaginaire n'accède vraiment à la symbolicité que s'il est libéré de toute fonction allégorisante, dans laquelle le concept précède toujours la production de l'image".
} 
por isso que uma obra pode causar profunda impressão em um espectador que não conhece o artista, que não sabe qual o movimento estético que ele segue e se o que está representado se refere a esse ou aquele fato histórico, a essa ou àquela personagem. O poder da experiência simbólica está em "[...] em religar os dados dos sentidos à fonte do sentido que ultrapassa de longe os dados particulares e contingentes da experiência" (Wunenburger, 2002, p. 22, tradução nossa) ${ }^{6}$. Ultrapassando as particularidades, a fonte desse sentido é transcendental. Por isso, embora o sujeito imaginante tenha sua biografia, suas respostas simbólicas sempre vão além dela, sempre participam de um coletivo.

É nessa ultrapassagem do sentido biográfico e histórico sem recair na ficção que reside o mistério do sermo mythicus. A dificuldade que o mito oferece para os estudos do imaginário é grande: não se trata nem de criação gratuita, posto que é motivado simbolicamente e na repetição está sua característica estrutural, nem de verdade histórica, posto que não deriva de biografias. Não dependendo de fatos históricos, o mito não se confunde com lendas nem com folclore. Não sendo criação arbitrária, não se confunde com fábulas. Já o caráter redundante do mito oferece uma possibilidade interessante de estudo por meio do mapeamento das repetições dos pequenos temas míticos que se inserem na narrativa maior, ou seja, dos mitemas. A repetição é característica do sermo mythicus porque as imagens simbólicas são necessariamente polissêmicas. Para indicar e restringir o sentido, o mito repete a grande narrativa nos detalhes, variando as formas.

No entanto, o inventário puro e simples das imagens obsessivas presentes em uma narrativa não é suficiente nem para se compreender seu sentido geral nem para se afirmar seu caráter mítico. O sentido geral do mito advém do modo constelativo das imagens que o compõem. Formando-se as constelações não por analogia, e sim por homologia (DURAND, 2016), não serão as semelhanças de papeis que determinarão a atratividade entre imagens simbólicas, e sim as semelhanças de nascimento. Pouco importa se a narrativa confere tanto à árvore quanto à escada de Jacó a função de acesso ao céu; para determinar se as duas imagens simbólicas constelam, é preciso verificar se provêm de um mesmo schème, ou seja, da mesma lógica - e não de um mesmo arquétipo, já que, como visto antes, várias lógicas podem participar de um mesmo arquétipo, na sua complexidade e contraditoriedade ${ }^{7}$. O único meio de compreender isso é examinando a

\footnotetext{
${ }^{6}$ No original francês: "[...] dans celle de relier les données des sens à une source du sens, qui dépasse de loin des données particulières et contingentes de l'expérience".

7 Por isso, é no mínimo estranho diagnosticar essa ou aquela narrativa como sendo orientada por esse ou aquele arquétipo com base em um grande traço substantivo, uma ideia homogênea e apaziguada. Em que pese a intangibilidade do arquétipo, sua
} 
narrativa inteira, verificando o modo de as imagens se relacionarem umas com as outras. E, embora seja provável que a escada, por exemplo, nasça do schème ascensional, isso não é dado, não sendo impossível que o material da escada prevaleça sobre sua forma. A madeira pode nascer do schème rítmico por sua remissão à árvore que reflete os ciclos da natureza, do mesmo modo que a árvore, embora possa servir para se atingir um ponto mais alto no espaço, induzindo à detecção de um schème ascensional na sua origem simbólica, também serve ao schème rítmico na medida em que evoca a passagem do tempo e, por que não, também ao schème da descida na sua potencialidade para atenuar a queda.

Percorrer o caminho de volta de uma imagem simbólica desde sua manifestação em um sermo mythicus até seu nascedouro schématique solicita atenção mais às ações que expressam essa imagem do que às figurações epítetas e/ou substantivas. Isso porque o imaginário nasce da consciência do tempo que passa, ou seja, da consciência da perecibilidade do corpo. É ao corpo, então, que cabe expressar as respostas que a simbolização constrói, ou seja, a ação é incontornável ao simbolismo, está na origem de todas as outras expressões, das quais os schèmes são a quintessência engramática. Eles são comunicados por meio dos três grandes movimentos que estão na base da pluralidade de respostas à angústia causada pelo tempo que passa e que constituem o imaginário: distinguir, (con)fundir, e os princípios lógicos respectivos, exclusão/identidade, analogia/similitude e causalidade. Assim, os verbos no discurso oral e escrito e os gestos no discurso visual são indicadores fundamentais para a compreensão do schème que se encontra na base das constelações de imagens simbólicas que constituem as narrativas míticas, entre as quais as comunicacionais.

\section{O lugar do sermo mythicus na tópica sociocultural}

Sendo superestrutura do imaginário, o mito está presente mesmo onde o pensamento racional acredita só haver espaço para clareza, distinção, univocidade, notadamente nas ciências duras, mas também na filosofia, na religião e, claro, na arte e na comunicação. Se entendermos o mito simplesmente como uma narrativa organizadora, tudo o que apresenta explicações de mundo participará do mito. A amplitude da definição traz, assim, dificuldades à pesquisa quando se estabelece a anterioridade fundadora do imaginário e se deseja avançar sobre as compreensões

presença nas produções não sendo mais do que ideias gerais que as perpassam, ele é, pelo menos, sempre bifronte, abrigando ao mesmo tempo duas imagens opostas. Não há Grande Mãe benfazeja sem sua correspondente cruel atuando conjuntamente. 


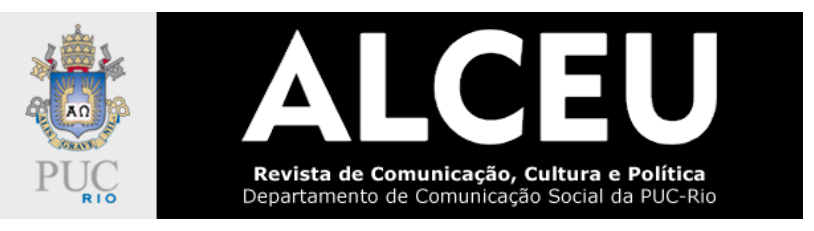

acerca desses sistemas de imagens em vista de sua eficácia sobre a realidade. Pois, se o imaginário é fator de equilíbrio psicossocial (DURAND, 2000), o mito é sua superestrutura, e toda a produção humana pode ser entendida como também mítica, já que "[...] o imaginário constitui as regras do jogo em todos os níveis de nossa relação com o mundo" (THOMAS, 1998, p. 17, tradução nossa $)^{8}$, não resta nada mais a fazer senão esperar que o mundo siga seu curso.

Compreender o jogo simbólico é compreender que as representações não nascem inteiramente de nós, que o inconsciente antropológico atua sobre nós tanto quanto nossas construções sociais, políticas e culturais. Nesse sentido, são inócuas as demonizações tanto quanto as angelizações do imaginário. Renunciar à atenção crítica sobre o imaginário, supondo que tudo o que o expressa é necessariamente bom, nada mais é do que cair na mesma armadilha do simplismo, da falta de complexidade conceitual que afirma como ilusório todo o imaginário. É, em suma, ignorar as enormes forças que movimentam os sistemas de imagens e submeter-se a elas como à fatalidade. Para avançar sobre o entendimento da dinâmica do imaginário, é necessário introduzir nuances - não exatamente distinções - que permitam - já que estamos falando de movimento - a detecção do sentido das imagens, ou seja, de sua direção mais do que de seu significado.

Não se trata apenas de perceber como o mito se distancia da fábula, da lenda, do folclore etc., como perceber também as mutações de um mesmo mito ao circular pelas instâncias que se definem pelos diversos graus de consciência sócio-antropológica denominados por Durand (1996, p. 141 e seguintes) como tópica sociocultural. O autor francês se inspira na nomenclatura da psicologia para indicar três níveis da tópica: um nível fundador arquetípico, chamado de "isso" estável, correspondendo ao inconsciente coletivo; um nível alcançável pela psicossociologia, chamado de "ego", lugar dos papeis e da teatralização social; um nível do consciente coletivo, das institucionalizações, da codificação jurídica, da reflexão pedagógica etc., chamado "superego". O ponto fundamental sobre o qual Durand avançou e que fez com que sua teoria resgatasse a respeitabilidade do imaginário - e a antipatia da Rive Gauche dos anos 1960 - foi a afirmação de que esses três níveis são ligados uns aos outros através do sermo mythicus. Isso significa colocar o mito como o grande dinamizador das forças sociais e retirar do sujeito e das estruturas boa parte da autonomia sobre a história que se faz. Daí é compreensível a rejeição da teoria geral do

\footnotetext{
${ }^{8}$ No original francês: "[...] cet imaginaire constitue les règles du jeu à tous niveaux de notre relation au monde".
} 
imaginário no contexto intelectual francês da época marcado, como bem nota Cazenave (1980), por Hegel, Marx, Freud e pelas antinomias kantianas.

Ao circular pelos níveis da tópica sociocultural, o mito se transforma. Não poderia ser de outro modo, já que nenhum dos dois polos do trajeto antropológico - nem o das coerções nem o das pulsões - tem anterioridade na construção dos mitos, que são gerados pela ação mútua de um polo sobre o outro. Saído do nível arquetípico com toda sua força transformadora, o mito se faz conhecer nesse momento inicial como revelação. O simbólico que o compõe está então no auge de sua pregnância - e, por isso, também de suas contradições. Somos mais destinatários do que autores desse conteúdo simbólico, característica que permanecerá ao longo da movimentação do mito pelos níveis da tópica, embora tendo de ser ocultada e travestida para não impedir sua ascensão. O que vai se modificar no mito é exatamente sua pregnância simbólica, coagido que será pelas forças institucionalizadas do superego social. Não será, então, justo definir como mítica apenas a narrativa revelada e portadora de toda a pluralidade arquetipal porque não há outra forma de organização das imagens que não a mítica.

Por isso, temos a tópica sociocultural (DURAND, 1996), que distingue entre mitos ascendentes, descendentes e diretores, como vimos antes. Não para diferir entre autêntico e inautêntico ou entre cheio e vazio, vamos usar chamar aqui de pleno o mito que se encontra em um estágio de ainda quase latência, no seu ápice de pregnância simbólica, mas já desempenhando alguns papeis sociais, mesmo que valorizados negativamente, pois ainda o mito ainda não foi absorvido pelo ego social. Para chegar ao superego social, o mito precisa que suas imagens pregnantes simbolicamente se degradem em estereótipos que se impõem pelo mesmo procedimento que o mito pleno utiliza com suas imagens mais perturbadoras, a repetição obsessiva. Nesse processo, a polissemia inicial é reduzida, neutralizando-se, seja por distorção ou por simples eliminação, os aspectos simbólicos que não se coadunam com o mito diretor da época, ou seja, com o mito que preside a consciência social em um dado momento.

A redução da pregnância simbólica de um mito, embora possa ser sentida como nefasta, é justamente o dispositivo pelo qual o mito sobrevive ao longo dos tempos e das culturas, por meio de variações, adaptações, conformações. Os três níveis da tópica sociocultural antes mencionados indicam também as mutações míticas necessárias para que um mito pleno se torne um mito diretor. Suas contradições fundamentais devem ser desbastadas para que uma parte de sua narrativa seja aceita - por isso, um mito diretor jamais será pleno. 


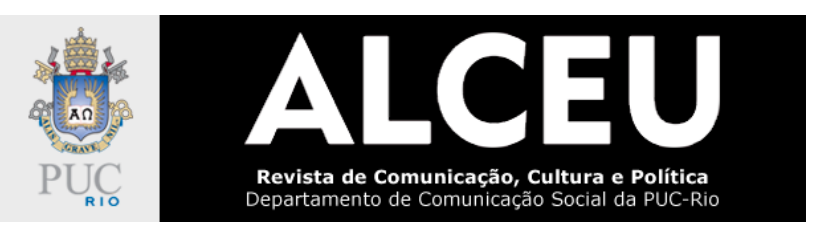

No momento em que toma o caminho da ascensão, o mito pleno se degenera; seus aspectos mais selvagens e contestatórios até são mantidos por algum tempo no ego social, se encarnando em papeis sociais desvalorizados. No momento em que finalmente esse mito se instala no superego social, os rastros de suas contradições estarão decididamente eliminados, expurgados até mesmo dos papeis sociais desvalorizados, que serão ocupados pelo próximo mito em ascensão.

\section{Desvalorização do mito}

No entanto, não se justifica que o mito seja depreciado em função de sua não adequação à definição como pleno. Embora, a princípio, os estudos do imaginário promovam uma valorização positiva do simbolismo no sentido de reconhecer sua importância fundamental para as sociedades, muitas vezes esses mesmos estudos, com as melhores intenções, redundam no rebaixamento do mito por meio dos métodos de suas abordagens. A desvalorização do mito é quase impossível de ser contornada na medida em que até seu registro escrito já constitui uma degeneração de sua forma ritualística oral fundadora. Brandão (2004) lembra bem que a poesia, o teatro e a arte figurativa são manifestações profanas do mito, submetidas a estéticas e políticas. É assim, segundo Brandão (2004), que os heróis da mitologia grega passam necessariamente por Atenas, cuja hegemonia política interessava ao poder. Ésquilo teria recomendado que o desejo proibido de Fedra pelo enteado jovem e casto fosse ocultado das representações teatrais.

No entanto, o que certamente mais contribui para a desvalorização do mito é sua interpretação a partir de chaves racionalizantes, que ignoram seu caráter simbólico, transformandoo em simples código a ser decifrado. Nesse sentido, tanto o alegorismo quanto o evemerismo têm sua participação na desvalorização do imaginário, segundo Eliade (1994). Embora remontem ao início da era cristã, ambas as práticas são ainda recorrentes mesmo nos estudos do imaginário, ainda que travestidas de metodologias por vezes bastante complexas, precedidas de fundamentações teóricas que recuperam com justiça os avanços da hermenêutica, mas que, talvez pela pressão do critério científico segundo o qual um caminho de pesquisa, se percorrido por outro pesquisador, tem de redundar nos mesmos resultados, acabam se rendendo a codificações mais ou menos disfarçadas, transformando princípios heurísticos férteis e dinâmicos como o dos regimes do imaginário em rígidas grades de análise.

Às vezes, alegoria e evemerismo são usados como sinônimos e, outras vezes, como antônimos. Em comum, ambos desvalorizam o mito, colocando-o, se não em oposição, pelo menos 


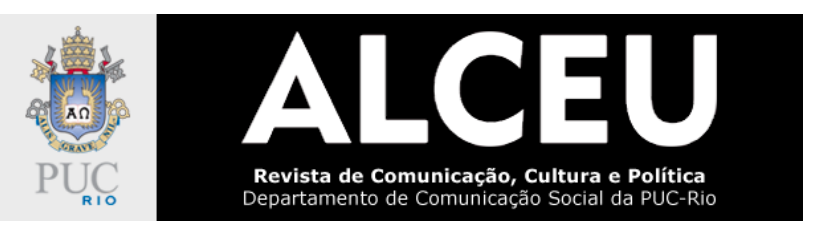

como paralelo e distinto da realidade. No entanto, tomam caminhos diferentes para fazê-lo. A alegoria é uma figura de linguagem que faz preceder o sentido literal pelo figurado, expressandose por meio das substituições, ou seja, um dado elemento do mito representa um outro elemento da realidade. O evemerismo se remete a seu criador, Evêmero, que teria vivido no século IV a.C. Essa tradição afirma que os deuses dos mitos são na verdade personagens históricos. Dessa forma, o sentido do mito não é transcendental, e sim histórico e social. Não será difícil detectar a contrario deuses e heróis em figuras conhecidas: de Ayrton Senna, Beatles, Che Guevara a Zumbi dos Palmares, é possível fazer o alfabeto inteiro com seus nomes porque analogias entre mitos e história são sempre possíveis - não quer dizer que sejam úteis. Em um só golpe, alegoria e evemerismo são acionados, afirmando-se o sentido literal sobre o figurado: os personagens são primeiro históricos para depois serem revestidos por uma analogia mítica.

Durand (1983) afirma que é por excesso ou por deformação que o mito se degrada até se esgotar na consciência social. Talvez não tenha tido a intenção de indicar erros que possamos cometer na pesquisa, mas sua apresentação das transformações às quais um mito pleno se sujeita é esclarecedora também a respeito dos equívocos a que o pesquisador do imaginário se expõe. Um dos primeiros erros é o excesso de conotação. Consiste em não detectar o abandono, pelo mito, de seu nome e de seu atributo. Um pequeno exemplo disso está, segundo Durand (1996), no engano de Nietzsche ao apresentar Zaratustra como Dionísio, mas Ihe conferindo os atributos de Hermes: dançarino da corda, entre a águia e a serpente. Talvez cometamos o mesmo erro ao identificar Hermes como diretor de nossa época, já que é ele o mensageiro dos deuses, presidindo as comunicações entre diversos planos. No entanto, os valores que pautam nossas comunicações (ou, talvez, melhor dizendo, nossas trocas de informação) tendem à exibição do quão prazerosa é a vida que levamos, como são deliciosas as comidas que comemos, quão é embriagante o vinho que tomamos, como é desejável o corpo que temos. A festa e o gozo da vida a qualquer custo parecem mais ligados a um Dionísio institucionalizado, do qual foram eliminados os aspectos iniciáticos, selvagens e perturbadores para restar apenas aquele que é o mais palatável na nossa sociedade do consumo: o prazer que se compra, um prazer que se configura mais como transgressão não só permitida como também esperada e que, pois, é já obrigação à transgressão - não teríamos já traços disso quando a revolução sexual e a pílula anticoncepcional não apenas liberaram as mulheres para o sexo sem funções reprodutivas como praticamente, de um dia para o outro, após centenas de anos de moral judaico-cristã, obriga-as a chegar ao orgasmo? Isso nos 


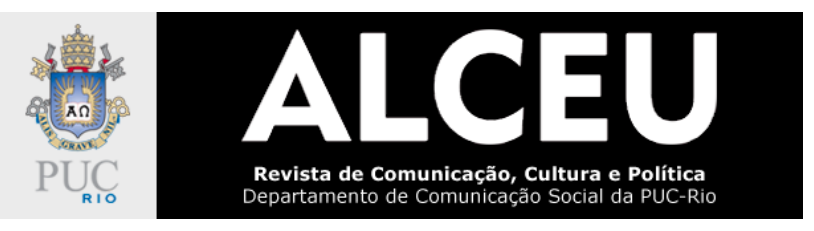

leva à heresia, que é um outro modo de o mito se desgastar e, no caso, de o pesquisador se enganar: valorizar um único mitema, ignorando os demais e enviesando o sentido pleno do mito.

A heresia tem um correlato no cisma, procedimento interpretativo que espelha a deformação do mito pela supressão de vários mitemas. Isso é bastante fácil de observar nas representações midiáticas dos mitos gregos feitas por exemplo, no filme de animação Hércules, dos Estúdios Walt Disney, em que o herói de Tebas é retratado simplistamente como um desajustado social que deseja se integrar à sociedade e ter boa reputação e que salva a mulher que o traiu. Os dois se apaixonam e vivem felizes para sempre. Malgrado a redução da narrativa mítica, necessariamente alógica, a uma narrativa coerente com a concepção histórica do tempo, o que mais distancia essas adaptações midiáticas é a supressão dos mitemas que indicam os atributos do mito pleno. A violência, a crueldade e a tormenta que é a existência de Hércules, arrastado para um destino trágico, são totalmente omitidos, retirando-lhe a potência perturbadora. Mesmo o cinema classificado pelos críticos como "autoral" não escapa aos cismas e heresias. A personagem Camille, interpretada por Brigitte Bardot no filme Le Mépris, de Godard, tem facilmente seus atributos físicos relacionados a Afrodite, como se vê em Lage (2013), que cita Vimenet (1991). Ora, relacionar a beleza e a sexualidade a Venus/Afrodite é reduzir o mito a um único atributo, glorificado sobretudo a partir de uma leitura renascentista do célebre episódio que antecede a Guerra de Troia narrada em llíada quando, nas bodas de Tétis e Peleu, o jovem Páris é obrigado a escolher a deusa mais bela: Hera, Atenas ou Afrodite. Todas são lindas. Como se sabe, o prêmio concedido por Páris a Afrodite se deve à barganha da deusa que em troca the prometeu o amor da mais bela mulher do mundo. Para além da negociação de Afrodite na conquista do título de mais bela deusa, importa aqui que um mito se reduz a alguns aspectos e oculta outros para sobreviver em um sistema cultural. Esse sistema funciona coercitivamente. Por isso, não é surpreendente que em tempos de apologia às aparências se reduza Afrodite à atração física. Seria interessante verificar os aspectos desse mito que são marginalizados para se compreender em que direção o imaginário está se movendo, mas o que interessa ressaltar aqui é a independência do simbolismo em relação às classificações de alta ou baixa cultura, arte e não arte etc.

\section{O mito na mídia}

As comunicações, pouco importa se interpessoais, da mídia alternativa ou da grande mídia, têm participação significativa na mitogênese ao se justificarem por colocar em circulação narrativas 


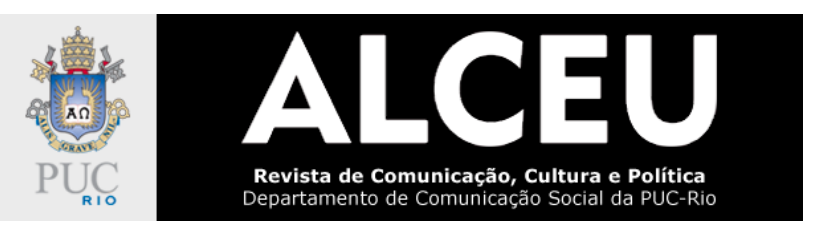

sobre praticamente tudo o que há no mundo. Os direcionamentos políticos e estéticos dessas narrativas não Ihes retiram, pois, o caráter mítico, constituindo-se antes em sinalizações do nível da tópica sociocultural em que determinado mito age com mais força. Inversamente, tais direcionamentos também não são fatores de constituição de um mito, como se poderia concluir a partir de uma afiliação a Barthes (1999) que afirma o mito como naturalização da história.

Se nas sociedades arcaicas o mito pleno era oral e transmitido por meio das religiões dos mistérios, sendo os documentos escritos do teatro já um desbaste de sua simbolicidade, o que acontece com o mito nas nossas sociedades em que as próprias comunicações praticamente impõem a publicização de toda a intimidade e o compartilhamento de todas as imagens? Há ainda espaço para o segredo e o mistério? Onde estão as sombras nas quais se gestam as transformações?

Os mitos visíveis na mídia estão institucionalizados ou muito próximos da institucionalização e, pois, já degenerados. É apenas de grau a perda do simbólico que atinge um mito nos diversos níveis da tópica sociocultural; a natureza simbólica das imagens persiste, embora degradada. Cumpre não tomar aqui as palavras degeneração e degradação como algo ruim; em se tratando de imaginário, não há bem e mal, e sim uma completude necessariamente alcançada por meio de compensações, como por exemplo quando o angelismo se faz acompanhar de violência, mas dizer que somente as coerções do momento histórico - sociais, políticas, culturais etc. - poderão valorar como desejáveis ou nefastas. O material empírico com que trabalhamos na Comunicação é na maior parte das vezes resultado da propagação frenética de imagens alijadas de alguns ou vários de seus aspectos. Multiplicando-se, elas compensam em número o que Ihes falta em polissemia. Ora, isso não absolve o pesquisador do imaginário de retirar do mito sua sacralidade. Mesmo um estereótipo é uma imagem; reduzi-lo a um código que reenvia a uma ideia simples é ignorar sua origem schématique e arquetípica. Não se está com isso dizendo que a pregnância dessa imagem será a mesma que a das imagens simbólicas que acontecem próximas ao polo pulsional. O que se afirma, sim, é que tratá-la como simples código impede a compreensão de sua potencialidade simbólica. É necessário respeitar a natureza simbólica de toda e qualquer imagem sem cair nem na armadilha do sentido reduzido. Pelo contrário, o que interessa é o desvelamento dos aspectos negados que levam ao destaque de apenas uns poucos sentidos. O papel do mitólogo das comunicações será, pois, antes o de diagnosticar os desgastes e usuras que o mito diretor sofre, desocultando seu potencial transformador, resgatando os mitemas suprimidos, acusando as 
heresias, a falsa denominação, mostrando enfim o que estamos perdendo ao institucionalizar esse mito pleno - e sem recair ele mesmo na prática do cisma, da heresia, da falsa denominação, do alegorismo etc.

Ora, compreender o mito pleno não passa por procedimentos científicos usuais, já que ele não é representado, e sim revelado. Evidentemente, se sua permanência dependesse das religiões dos mistérios que o ritualizaram, o mito não teria atravessado os tempos: foram suas representações que o mantiveram entre nós, permitindo-Ihe a sobrevivência nas mais agudas situações de positivismo, de materialismo, de racionalismo. Por outro lado, o desbaste promovido pelas representações não deve ter impedido que a revelação acontecesse, caso contrário o sermo mythicus não teria mais eficácia nenhuma. Então, em alguma instância marginal, os ritos continuaram a ser fiéis ao mito. Sem o rito, a representação de um mito é simplesmente palavra, ilustração. O mito é transformador quando é alcançado na participação ritual. No rito, o mito é revelado, seu sentido toma o ser de modo total, instantâneo e, sobretudo, intraduzível. Não se apreende um mito pelo compartilhamento da experiência.

A experiência do mito não pode ser reapresentada, por isso o mito pleno está no reino das coisas que não podem ser ditas nem repetidas. É perturbadora para o mitólogo das comunicações a entrada no reino das aporias até porque esse reino nos escolhe muito mais do que o escolhemos; somos destinatários do simbólico, e não seus tradutores. Ao passo que a componente coercitiva das imagens é facilmente mapeável usando-se ferramentas já bastante conhecidas na pesquisa em Comunicação tais como análise de discurso e análise de conteúdo e suas inúmeras variantes, o mesmo não se dá com a componente simbólica, que solicita a experiência.

É possível separar o código do simbólico? Mesmo que a componente coercitiva seja progressivamente maior na medida em que o mito se degrada, é de se perguntar se há ganho em separar o código do simbólico, mapeando o que for possível com as ferramentas tradicionais e deixando para um outro momento a adição da interpretação simbólica. A compreensão do mito, seja ele pleno seja ele já usurpado e/ou degradado, é necessariamente pessoal, o que não quer dizer nem subjetiva nem objetiva, já que o mito, como dito de outro modo mais acima, se coloca em uma esfera a-racional, nem histórica nem ficcional. Coerções e pulsões estão estreitamente imbricadas no sermo mythicus; tentar separá-las apenas aumentará as chances de cisma, heresia, falsa nominação na interpretação simbólica. 
Mesmo que se alcance o entendimento do simbólico por meio da revelação, imediatamente se coloca ao pesquisador o problema da sua expressão, já que esse sentido não é representável. A revelação simbólica, caso ocorra, só poderá ser vagamente descrita pela poética, a qual só será vagamente compreendida pelos iniciados que também já viveram o mesmo. Talvez a revelação simbólica só não seja mais improvável à pesquisa do que a aceitação pelo pensamento científico de que nem todas as verdades ganham ao serem expostas à luz da razão.

Ana Taís Martins

Professora do Programa de Pós-Graduação em Comunicação da UFRGS Doutora em Ciências da Comunicação pela ECA/USP ORCID: http://orcid.org/0000-0001-5203-7575

E-mail: anataismartins@icloud.com

Recebido em: 16 de maio de 2020.

Aprovado em: 18 de junho de 2020.

\section{Referências}

BARTHES, Roland. Mitologias. Rio de Janeiro: Bertrand Editores, 1999.

BRANDÃO, Junito de Souza. Mitologia grega. Volume I. Petrópolis, Vozes, 2004.

CASSIRER, Ernst. Filosofia de las Formas Simbólicas III: Fenomenología del reconocimiento. México: Fondo de Cultura Económica, 1998.

CAZENAVE, Michel. Castor, pollux et le taureau. IN: La galaxie de l'imaginaire. Dérive autour de l'oeuvre de Gilbert Durand. Paris: Berg International, 1980. p. 247-248.

CORBIN, Henri. L'imagination dans le soufisme d'Ibn'Arabî. Paris: Flammarion, 1976.

DURAND, Gilbert. A imaginação simbólica. Lisboa: Edições 70, 2000.

. Les structures anthropologiques de l'imaginaire. Paris: Dunod, 2016.

1983.

Mito e sociedade. A mitanálise e a sociologia das profundezas. Lisboa: A Regra do Jogo,

Introduction à la mythodologie : mythes et sociétes. Paris: Albin Michel, 1996.

ELIADE, Mircea. Mito e realidade. São Paulo: Perspectiva, 1994.

JUNG, Karl. G. Os arquétipos e o inconsciente coletivo. Petrópolis: Vozes, 2014. 
LAGE, Celina. Como filmar a Odisseia? Godard e o filme de Lang. Caderno Seminal Digital Ano 20, no 20, V. 20 (Jul-Dez/2013 - ISSN 1806-9142)

VIMENET, Pascal. Le Mépris. Jean-Luc Godard. Paris: Hatier, 1991.

MERLEAU-PONTY, Maurice. Fenomenologia da percepção. São Paulo: Martins Fontes, 1999.

SARTRE, Jean-Paul. L'imaginaire. Paris : Gallimard, 1986.

THOMAS, Jöel (org.). Introduction aux méthologies de l’imaginaire. Paris: Ellipses, 1998.

WUNENBURGER, Jean-Jacques. A árvore de Imagens. Intexto, Porto Alegre, UFRGS, n. 41, p. 58-69, jan./abr. 2018. DOI: http://dx.doi.org/10.19132/1807-8583201841.58-69. Acesso em 7/01/2019.

. La vie des images. Grenoble: PUG, 2002.

\section{Resumo}

Este artigo questiona a persistência mitogênica nas narrativas comunicacionais contemporâneas e os modos de investigá-la. Para tanto, apresenta o sermo mythicus como a narrativa fundamental que orienta a experiência humana em todas as épocas e culturas. Pergunta-se sobre a eficácia simbólica das transposições do mito na mídia, situando o mito no contexto do imaginário, relacionando-o a schèmes, arquétipos e imagens simbólicas. Em seguida, descreve as mutações necessárias a um dado sermo mythicus para que seja possível sua sobrevivência nas instâncias da consciência social. Aventa-se que o mesmo processo de usura e degradação sofrido pelo mito dá origem a enganos que levam os estudos do imaginário a desvalorizarem o sermo mythicus. Conclui que o simbólico permanece vivo mesmo nas imagens empobrecidas das narrativas míticas enrijecidas na consciência social e que o papel do assim chamado mitólogo das Comunicações é desocultar os sentidos reprimidos do mito. Esse trabalho afilia-se à Teoria Geral do Imaginário, principalmente através de G. Durand e J.-J. Wunenburger.

Palavras-chave: Comunicação. Narrativa. Imaginário. Mito. Símbolo.

\section{Abstract}

This article questions mythogenic persistence in contemporary communication narratives and the ways to investigate it. In order to achieve so, it presents sermo mythicus as the fundamental narrative that guides the human experience in all times and cultures. It questions the symbolic efficacy of myth transpositions in the media, situating it in the context of the imaginary, relating it to schèmes, archetypes and symbolic images. Subsequently, it describes the mutations necessary for a given sermo mythicus to survive in instances of social consciousness. It postulates that the same process of usury and degradation suffered by the myth gives rise to mistakes that lead the studies of the imaginary to devalue the sermo mythicus. It concludes that the symbolic remains alive even in the impoverished images of mythical narratives stiffened in social consciousness and that the role of the so-called Communications mythologist is to uncover the repressed meanings of myth. This work is affiliated to the General Theory of the Imaginary, mainly through G. Durand and J.-J. Wunenburger.

Key words: Communication. Narrative. Imaginary. Myth. Symbol. 


\section{Resumen}

Este artículo cuestiona la persistencia mitogénica en las narrativas comunicacionales contemporáneas y las formas de investigarla. Con este fin, presenta el sermo mythicus como la narrativa fundamental que guía la experiencia humana en todas las edades y culturas. Pregunta sobre la efectividad simbólica de las transposiciones del mito en los medios de comunicación, colocando el mito en el contexto de lo imaginario, relacionándolo con esquemas, arquetipos e imágenes simbólicas. Luego, describe las mutaciones necesarias para un sermo mythicus dado para que sea posible sobrevivir en los casos de conciencia social. Se sugiere que el mismo proceso de usura y degradación que sufre el mito da lugar a errores que llevan a los estudios de lo imaginario a devaluar el sermo mythicus. Concluye que lo simbólico permanece vivo incluso en las imágenes empobrecidas de narraciones míticas endurecidas en la conciencia social y que el papel del llamado mitólogo de las comunicaciones es revelar los significados reprimidos del mito. Este trabajo está afiliado a la Teoría general de lo imaginario, principalmente a través de G. Durand y J.-J. Wunenburger.

Palabras clave: Comunicación. Narrativa. Imaginario. Mito. Símbolo. 